\title{
Landlines, Cellular, and Internet Protocol Subscribership
}

\author{
Johannes H. Snyman \\ Metropolitan State University of Denver
}

This research study is about the current subscriber status of the three dominant telephone technologies: landline, cellular, and Internet Protocol. After a brief history of the three technologies, data from the Federal Communication Commission (FCC) was used to determine the number of subscribers from 1997 to 2018, the last date of published data. Results indicate that landline subscribers are in steep decline. However, a complete shut-down of the system is not in sight yet. The number of cellular telephone subscribers is still growing steadily and growth is predicted to continue. The number of Internet Protocol subscribers has been growing fast but due to increased competition will begin to slow down in the future.

Keywords: landline, cell, internet protocol phones, subscribership

\section{INTRODUCTION}

The telephone industry is 145 years old in 2021! The official start of the industry has always been associated with Alexander Graham Bell filing a patent for the telephone on March 7, 1876. However, Bell quickly became the subject of many lawsuits after that date, being accused of having stolen Antonio Meucci's "teletrofono" invention. In an experiment in 1849, Meucci heard the voice of a person over an electrically charged copper wire for the first time. He conducted several successful experiments afterwards and tried to file a patent for his "teletrofono" in 1871 but failed due to financial and medical problems (Demetri, 2019). After his death in 1889, the lawsuits against Bell became moot and Bell was considered the inventor of the "telephone," which is Bell's name for Meucci's "teletrofono." In 2002, the U.S. Congress stripped Bell's name off the patent and placed Antonio Meucci's name on it due to extensive lobbying and discussions with Meucci's family and friends (Bell did not invent the telephone, 2002). However, after a search of websites in 2020, most authors and websites still attribute the invention of the telephone to Bell!

The telephone industry grew rapidly after March 7, 1876, from one telephone in 1876 to 600,000 by 1900. By 1910, there were 5.8 million telephone connections in the U.S. and 30 million by 1948 . This is astonishing growth from 1876 to 1948, but in just 12 years from 1948, the number of phone connections more than doubled to 80 million and more than doubled again by 1980 when the number reached 175 million (1870s-1940s, n.d.). In order to manage all these telephone connections and lines, Bell's father-inlaw, Gardner Greene Hubbard, founded the Bell Telephone Company on July 9, 1877, which became an incorporated company on July 30. In 1879, the Bell Telephone Company merged with the New England Telephone and Telegraph Company, also founded by Hubbard (Benzinga, 2018). In 1880, the company merged again but this time with the American Speaking Telephone Company and became the American Bell Telephone Company. In 1885, the company evolved into the American Telephone and Telegraph Company (AT\&T) (Bellis, 2020b). 
There has been a myriad of telephone designs invented since Bell's foundational telephone of 1876 (Vanderbilt, 2012). However, there are three dominant types of telephone systems to which telephones connect and one system that is a distant fourth in the industry. Landline, cellular, and Internet Protocol telephone systems are the dominant systems today (Elizabeth, 2020), and the satellite telephone system is a distant fourth. Satellite phones are designed for mostly outside use and used in areas where cell phone coverage is weak. In addition, time lags, calling costs, and line-of-sight to the satellite from a satellite phone are also negatives against widespread satellite telephone use (Are satellite phones, n.d.). This research study involves a brief history of each of the dominant telephone systems, an assessment of the past and current number of subscribers, and a prediction of the future for each system.

\section{HISTORY OF LANDLINE, CELLULAR, AND INTERNET PROTOCOL SYSTEMS}

The evolution of the telephone or telecommunications industry from 1876 until today (2021) has been driven predominantly by technological innovations from the beginning. The most significant technological innovations, however, have occurred since the 1980s (Stone, 2015). Bell's landline or analog telephone system was the first system. For more than 100 years, these analog copper lines and phones connected person-to-person and business-to-business. Cellular and Internet Protocol telephone systems were invented during the 1980s.

\section{Landline Telephone System}

Telephones produced and sold between 1876 and 1878 were privately owned or leased by businesses in pairs to connect them directly to each other. On January 28, 1878, George Coy, Herrick Frost, and Walter Lewis created the first commercial telephone exchange, connecting many landline copper lines to each other, in New Haven, Connecticut. Coy also created the first, very basic, telephone switchboard and produced the first printed telephone directory, consisting of 11 entries (Smith, n.d.). In 1915, the first coast-to-coast phone call from San Francisco to New York was made using five telephone switch operators. It took 23 minutes to set up and connect two callers to each other. In 1943, AT\&T created the first automated switchboard, which used one telephone switch operator. It was not until 1951 that AT\&T created a direct long-distance service (Marcus, 2007).

The landline telephone service, also called the Plain Old Telephone Service (POTS), and the analog switches and networks, also called the Public Switched Telephone Networks (PSTN), were considered a natural monopoly due to the high fixed costs that make it very difficult to have more than one company in such an industry (Pettinger, 2016). Without government regulation, natural monopolies can abuse their power; thus, extensive federal and local regulation is necessary. A countrywide network must be established that can accommodate numerous connections and calls. This creates an economy of scale that allows costs to fall. However, the analog telephone industry experienced high inefficiencies and maintained a large labor force in order to maintain and expand the network. To recover these high costs, the industry charged high prices during peak times and low prices duringoff-peak times (Stone, 2015).

\section{Cellular Telephone System}

Experimentation with cellular or wireless telephone technology using radio waves started during World War I. During World War II, mobile phones that used radio waves were widely used. Bell Laboratories used this technology and developed a mobile phone system for cars in 1946 in St. Louis, Missouri (History of mobile, n.d.). AT\&T proposed that this mobile car phone technology could be extended beyond cars and asked the Federal Communications Commission (FCC) to allow them to explore this hypothesis. The FCC granted AT\&T a limited range of frequencies to conduct the research in 1947 but reconsidered its decision in 1968, stating that they would grant the rights to the wide use of cellular technology if AT\&T and Bell Laboratories could make it work; subsequently, a small, low-powered cellular system was developed by AT\&T and Bell Laboratories (Bellis, 2020a).

Martin Cooper, a Motorola engineer, is generally considered the inventor of the first modern cell phone (Bellis, 2020a). He made the first publicized mobile phone call on April 3, 1973 to Joel Engel, the head of 
research at Bell Laboratories, with a handset that weighed 2.5 pounds and was 10 inches long. No wonder it was called a "brick!" These first mobile phones could only be used for 20 minutes at a time and the battery took 10 hours to charge (Goodwin, 2019). Motorola applied for a license to produce and sell their cell phone, but the FCC instructed them to make technological changes. It took 10 years for Motorola to overcome technological and several regulatory problems imposed by the FCC. Commercial cell phone service finally started on October 12, 1983, in Washington DC and Baltimore by Cellular One, using a smaller redesigned Motorola cell phone that weighed 16 ounces (Alfred, 2008; Wolpin, 2014).

\section{Internet Protocol Telephone System}

Internet Protocol (IP) or Voice over Internet Protocol (VoIP) refers to transferring voice signals between IP addresses. Voice signals are converted into "packets" and then transmitted. The sending IP address compresses the voice signal and the receiving IP address decompresses the signal. In 1938, Homer Dudley, a Bell laboratory engineer, created the first voice signal transferring device, called a Vocoder, which was used in World War II to send messages via the SIGSALY system, created for this purpose. However, the Internet is needed to make Internet phone calls. This was realized when the U.S. military built the first Internet (ARPANET) in 1969 (Stone, 2020).

In 1973, Bob McAuley, Ed Hofstetter, and Charlie Radar created the first voice packet over ARPANET using Linear Predictive Coding (LPC), the first VoIP software. In 1974, the first voice data packets were successfully transferred. In 1976, the first conference call over LPC took place. In 1982, LPC was used over a local cable network. In 1980, CompuServe started the first large-scale commercial Internet chat service via computers (Stone, 2020). During the 1990s, VoIP services were mostly used for marketing purposes and by the end of the decade, VoIP calls comprised only 3\% of all phone calls. It was not until 2004 that VoIP became available to everyone (VoIP history, n.d.).

VoIP was initially considered as a telephone only, an alternative to copper line telephones, because it was accessed over PSTN. The system had poor quality because the PTSN system was not built for data packet transfers. VoIP needed a new technology and broadband was the answer! The increased bandwidth and high-speed internet connection instead of an Ethernet connection via copper or fiber-optic lines significantly reduced the cost of the VoIP telephone system. There is no network topology required, such as the arrangement of nodes, switches, routers, and connections in a network. VoIP technology has many benefits over analog service, which explains why the technology expanded rapidly in popularity. Subscriptions grew by $40 \%$ in 2001 and another 43\% in 2003 (Clancy, 2018). Users can use their computer or smartphone and can program desktop VoIP phones, which makes the technology mobile and very flexible. There are also significantly more hardware and software suppliers, which increases competition and lowers the costs. Unuth (2019) concluded that lower costs and increased flexibility make VoIP technology a superior technology over analog technology. VoIP technology also provides the full range of telephone services, video calling, videoconferencing, digital whiteboards, and voice email services.

\section{ASSESSMENT OF THE NUMBER OF SUBSCRIBERS OF EACH TELEPHONE SYSTEM}

Telephone companies generate revenue in a variety of ways: voice service or telephone calls, video service or television programming, date service or providing internet access, and text service. They also generate revenue by providing network connectivity between companies and provide wholesale circuits to companies who are heavy network users. Telephone calls have always provided most of the revenue, but this has been changing to data service and the others mentioned above in recent years (Beers, 2019).

Three performance metrics are reported on a regular basis by telephone companies: the average revenue per user (ARPU), the churn rate that measures the number of subscribers who left a company, and the growth rate of the number of subscribers. The subscriber growth rate is the preferred metric in the industry to determine the future viability of a telephone company. Companies report this metric as "net additions," which is the difference between subscribers gained and lost (What are the best metrics, 2020). The number of landlines operated and in use by residential and business customers of telephone companies is another metric used by telephone companies such as AT\&T and Verizon (Snyman, 2020). 
To assess the current state of the landline, cellular, and Internet Protocol telephone systems, data provided by the FCC from June 1998 until today was used. The FCC reports twice a year, at the end of June and December, on the status of the number of landline telephone lines and the number of cellular and Internet Protocol subscribers. The first Local Telephone Competition Report was released December 1998, starting with data at the end of December 1997 (FCC, 1998). The report was created in response to the Telecommunications Act of 1996 (Osbourne, 2000), which deregulated the telecommunications industry and allowed competitors to enter the industry previously dominated by AT\&T and the Regional Bell Operating Companies (RBOCs). The FCC released the Local Telephone Competition Report until December 2013. In 2014, the name was changed to the Voice Telephone Services Report to incorporate the change from the analog or landline telephone system to the cellular and Internet Protocol telephone systems (Snyman, 2020).

\section{Landline End-Users From December 1997 to December 2018}

The Telecommunications Act of 1996 created two types of telephone companies, Incumbents and Competitors. A Local Exchange Carrier (LEC) is responsible for connecting customers to local exchanges (the place where local residential and business phone lines terminate) and then re-routing the phone call to another local exchange or to a long-distance carrier. After the Telecommunications Act of 1996, these local exchanges became a shared space (Roos, n.d.). The original owner and operator of the local exchange was called an Incumbent Local Exchange Carrier (ILEC) and was required to sell access to its network to new entrants and competitors, called Competitive Local Exchange Carriers (CLEC), in addition to maintaining the equipment and services for all customers. The services, or access, to the local exchanges had to be sold to CLECs at wholesale prices. The CLECs also had the option of choice regarding which specific network pieces (such as loops, switches, and lines) to which they wanted access. This ability to access existing networks greatly reduced barriers to entry for new firms and significantly increased competition. CLEC telephone services, reported for the first time by the FCC in December 1999, grew quickly (see Figure 1). In December 2008, the FCC changed from CLEC to NON-ILEC, which is defined as "a voice-service affiliate of an ILEC that is operating outside the ILEC's traditional service area" (FCC, 2010).

Figure 1 indicates that ILEC end-user landlines reached their peak in December 1999 at 181,203,000. By June 2005, CLECs and NON-ILECs operated 33,891,000 end-user landlines, which is the highest number reached according to the FCC reports. Since December 1999, the number of ILEC end-user landlines has been in a steep decline in comparison to CLEC and NON-ILEC end-user landlines, which have been declining at a smaller rate. 
FIGURE 1

NUMBER OF U.S. END-USER LANDLINES FROM DECEMBER 1997 TO DECEMBER 2018

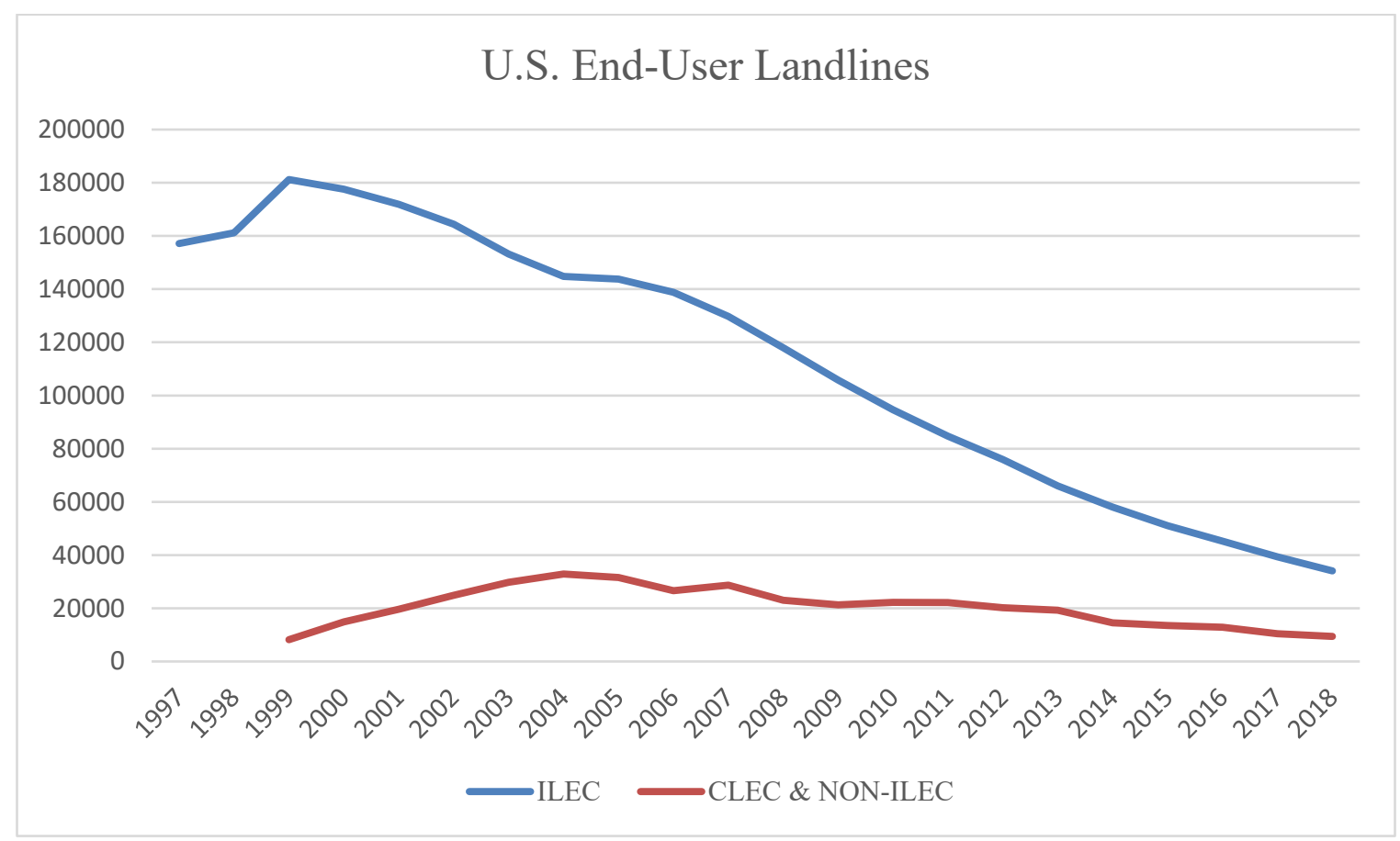

There are several reasons for the demise of the 100+ year-old copper telephone line networks. The most significant reasons are no doubt the invention of cellular and Internet Protocol technology, and the World Wide Web (WWW) by Tim Berners-Lee in 1989. However, the commercialization of the WWW did not start until April 30, 1993, when the European Organization for Nuclear Research (CERN) made the web available to everyone (Grossman, 2018). The WWW not only allowed for the transmission of data, but also for voice and video in a more effective and efficient way than the aging copper lines and equipment did in the 1990s and today (Downes, 2014). In fact, in 2009, AT\&T wrote a letter to the FCC and asked if it could turn off POTS and PSTN by 2020 (Sims, 2018).

\section{Cellular Subscribers From December 2008 to December 2018}

Cellular subscribership in the U.S. has grown very fast. The Cellular Telecommunications Industry Association (CITA, n.d.) has tracked the number of subscribers since 1985, when there were only 340,213. By 1990 , the number of subscribers reached 5,000,000. By 2000, the number of subscribers increased by $119 \%$ to 109.5 million. In 2008, the FCC began reporting the number of mobile subscribers (see Figure 2). Average growth has been $2.4 \%$ per year until December 2018, when the number of U.S. subscribers peaked at $345,225,000$. 
FIGURE 2

NUMBER OF U.S. CELLULAR SUBSCRIBERS FROM DECEMBER 2008 TO DECEMBER 2018

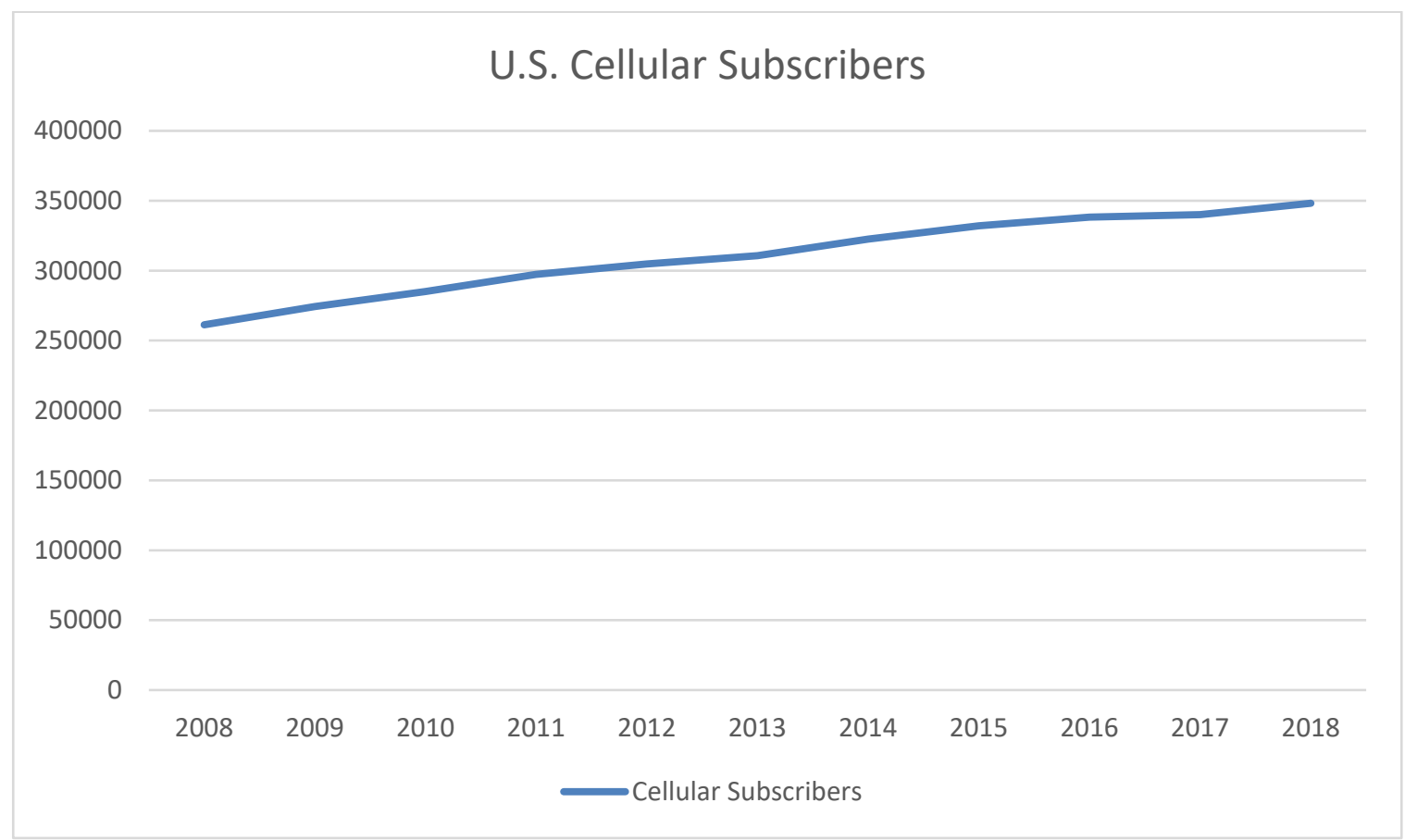

Internet Protocol Subscribers From December 2008 to December 2018

According to Figure 3, the number of VoIP subscribers listed in the FCC's Local Telephone Competition and Voice Telephone Services Reports from December 2008, when the FCC started to survey VoIP services to December 2017, indicates a fast-growing service. However, the total number of VoIP subscribers as of December $2017(66,585,000)$ is significantly below the number of switched access telephone lines in December $2000(192,555,000)$, when the analog service reached its largest number of subscribers. This difference must be considered in conjunction with the number of smartphone subscribers and analog subscribers still in existence. 
FIGURE 3

NUMBER OF U.S. INTERNET PROTOCOL SUBSCRIBERS FROM DECEMBER 2008 TO DECEMBER 2018

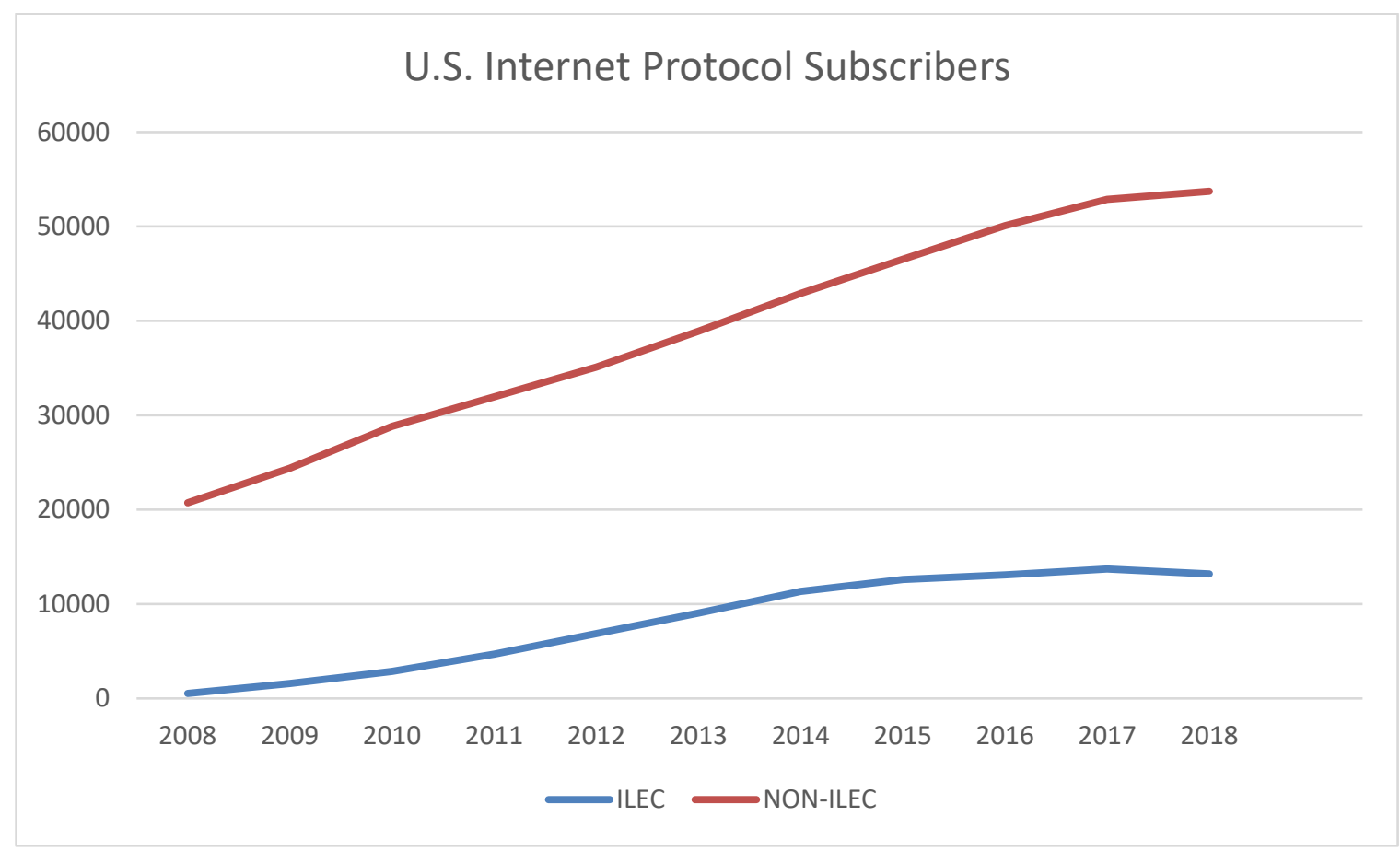

\section{THREE TELEPHONE TECHNOLOGIES COMBINED}

Separately, as of December 2018 FCC data, the three telephone technologies, landline, mobile and VIOP, have presented a confusing picture about growth in the number of subscriptions. Landline telephone service has been in decline for several years now, mobile technology has been growing but only at $2.4 \%$ per year, and Voice over Internet Protocol's growth is slowing down. Given this state of the three segments, what is the state of all three combined?

To get a picture of the combined effect, the numbers of subscribers of the three technologies were added together. According to Figure 4, the growth of subscribers was in decline from 2008 to 2011; however, this is due to the FCC not reporting the number of mobile technology subscribers until 2011. Since 2011, the number of subscribers to all services has been growing but at a very slow pace as graphed in Figure 4. 


\section{FIGURE 4 \\ COMBINED NUMBERS OF ALL U.S. TELEPHONE SUBSCRIBERS FROM DECEMBER 2008 TO DECEMBER 2018}

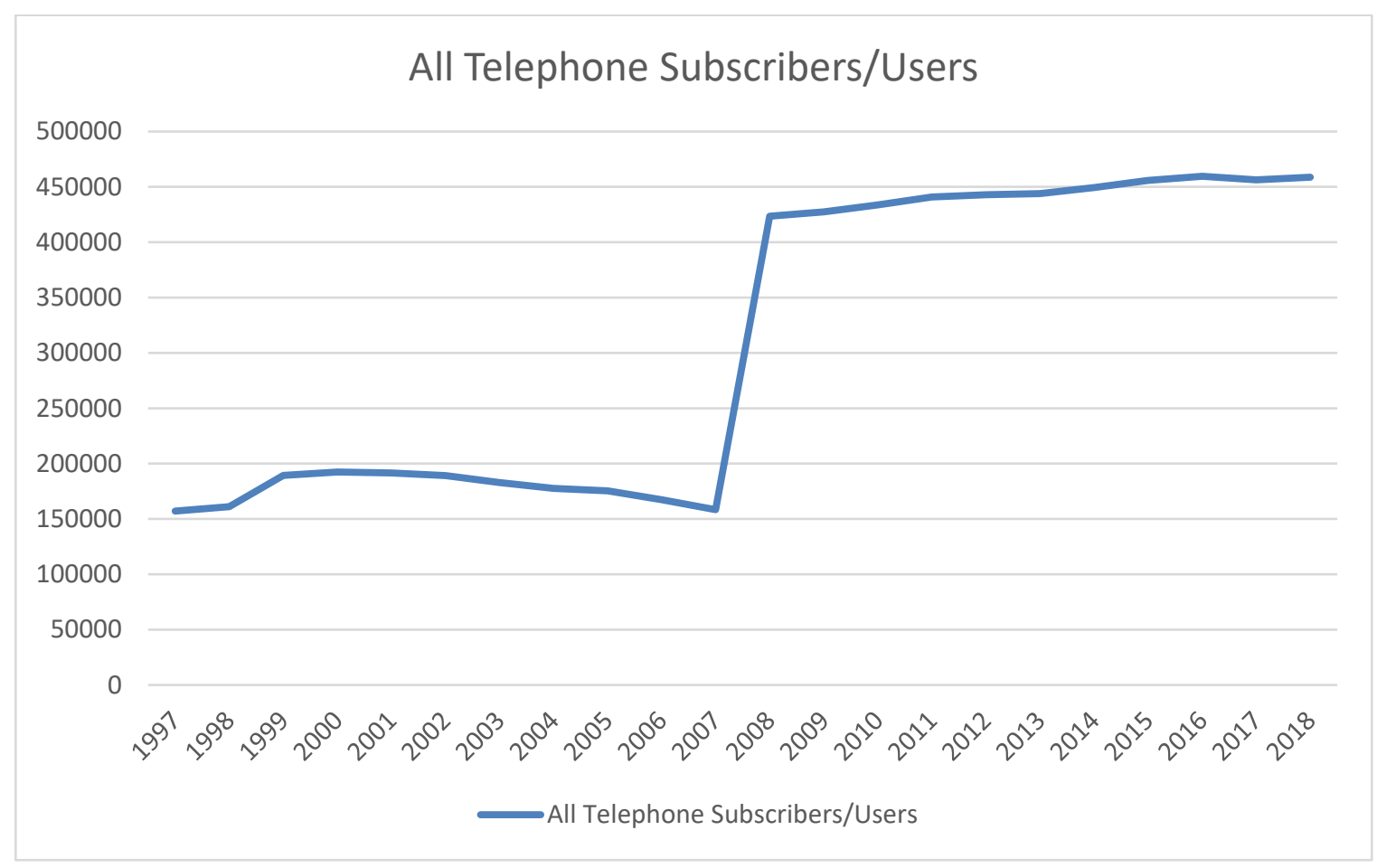

\section{THE FUTURE}

From a general perspective, the future of the three telephone technologies will be influenced by technological innovation, new devices, customer service, and regulatory rules. The new 5G (Fifth Generation) wireless network will deliver on the demand for high-speed connectivity, providing ultrafast speed with excellent reliability and bandwidth. Many industries will benefit from the innovation. Artificial intelligence and machine learning, growth in cloud platforms, the Internet of almost Everything, and increased use of video communications will facilitate the social aspects of remote and office work (Roldan, 2021). Customer service will also need to increase due to the new technology creating new and advanced customer needs. The telecom industry will need to adapt and change to compete for customers (Perrin, 2021), and stricter regulations will be enacted (Moses, 2021).

\section{The Future of Landline Technology}

What does the future hold for landlines? In 2013, the FCC predicted that landline service would exist for only another 10 years due to phone companies abandoning the maintenance and service of their copper line networks (Dampier, 2013). 2018 was the original phase-out date; however, the approval to end landline service was to take place on a state-by-state basis (Sims, 2018). In addition, the FCC (2017) has made rules and options for customers when they lose their landline service. However, the phase-out did not occur as planned. Then 2020 was set as the next phase-out date (Sims, 2018). This phase-out plan also did not take place. In fact, in an online forum, an AT\&T representative stated that AT\&T is no longer planning to phase out landlines and will not discourage people from getting a landline. This stance may be due to the FCC 2017 rules that required landline carriers to provide alternatives to disability services, fire and security alarms, medical devices, emergency services, and fax machines (Rankin, 2021). Hence, the phase-out date of landlines is still unknown and no official statements have been made by carriers or the FCC. 


\section{The Future of Cellular Technology}

The number of U.S. cellular subscribers has grown consistently from 2008 to 2018 (see Figure 2). The data in the figure include all types of cell phones of cell phone companies. There are three main types of cell phones: basic, feature, and smartphones. Basic mobile phones can make a voice call, send and receive SMS (short message service) messages, and use USSD (unstructured supplementary service data) such as a callback service and checking account balances. Feature mobile phones, on the other hand, include cameras and have greater storage than basic mobile phones. They can also access the Internet and have a standard numeric keypad. Smartphones have advanced capabilities in comparison to feature mobile phones. Users can add applications and each phone has a full-featured operating system and can connect to Wi-Fi and other networks (eMarketing, n.d.). The smartphone, however, has become more prevalent than the basic or feature mobile phone over time (Melendez, 2019). According to O'Dea (2021), smartphone user numbers are projected to grow from 274.1 million in 2018 to 301.65 million in 2022 , a $10 \%$ growth rate.

What will cell phones of the future look like? Cell phones will be flexible, bendable, and foldable. Some will be able to project holograms and could be used as remote controls due to the Internet of almost Everything and smart technology. New phones will have higher quality cameras, longer and improved battery life, and more powerful processors with every new version (Zak, 2020).

\section{The Future of Internet Protocol Technology}

According to Figure 3, the Internet Protocol growth rate started to decline in 2017 and through 2018. Moses (2021) predicted a decline of $0.1 \%$ that will continue through 2021 and attributed the decline in growth to the fierce competition from substitutes such as Apple's FaceTime and Facebook's Messenger.

The continued rollout of $5 \mathrm{G}$ mobile networks will enhance the quality and reliability of mobile Internet Protocol technology needed to compete against substitutes mentioned above and to realize or exceed the Ibis World industry forecast from 2021 to 2025 of $1.0 \%$ annualized growth rate (Moses, 2021). However, this growth forecast combined with low infrastructure costs will lead to more competition for the two dominant wireless Internet Protocol providers (Skype and Vonage), especially from big companies like Zoom and Microsoft and uncertainty about increased regulations. Also, mobile network providers, AT\&T, Verizon, and T Mobile, may try to reduce the access Internet Protocol mobile providers. Moses (2021), in considering these circumstances, forecasted a downturn in the annualized growth rate in 2026.

\section{REFERENCES}

Alfred, R. (2008, April 3). April 3, 1973: Motorola calls AT\&T...by Cell. Retrieved January6, 2021, from https://www.wired.com/2008/04/dayintech-0403/

Beers, B. (2019, July 2). What is the telecommunications sector? Retrieved January 15, 2021, from https://www.investopedia.com/ask/answers/070815/what-telecommunications-sector.asp

Bellis, M. (2020a, January 13). The history of cellular phones. Retrieved January 7, 2021, from https://www.thoughtco.com/martin-cooper-history-of-cell-phone-1989865

Bellis, M. (2020b, January 27). How the telephone was invented. Retrieved December 21, 2020, from https://www.thoughtco.com/history-of-the-telephone-alexander-graham-bell-1991380

Benzinga, E.B. (2018, July 9). This Day in Market History: Bell Telephone Company Is Founded. Retrieved December 19, 2020, from https://finance.yahoo.com/news/day-market-history-belltelephone-165905595.html

Clancy, E. (2018, September 10). The history of VoIP. Retrieved January 31, 2021, from https://medium.com/@eoin_61466/the-history-of-voip-7f0a0b2e5369

CTIA - Industry data. (n.d.). The wireless industry data. Retrieved September 2, 2019, from https://www.ctia.org/the-wireless-industry/infographics-library

Dampier, P. (2013, July 8). FCC: Landlines will only exist another 5-10 years, AT\&T wants out by 2020. Retrieved April 10, 2021, from https://stopthecap.com/2013/07/08/fcc-landlines-will-only-existanother-5-10-years-att-wants-out-by-2020/ 
Demetri, J. (2019, June 10). Antonio Meucci. Retrieved December 19, 2020, from https://www.lifeinitaly.com/heroes-villains/antonio-meucci

Downes, L. (2014, March 28). The End of the Line for the Analog Phone Network. Retrieved March 20, 2021, from https://hbr.org/2014/03/the-end-of-the-line-for-the-analog-phone-network

Elizabeth, M. (2020, December 9). What are the different types of telephone systems? Retrieved December 19, 2020, from https://www.wisegeek.com/what-are-the-different-types-of-telephonesystems.htm

Elon University. (n.d.). 1870s-1940s: The telephone. Retrieved December 24, 2020, from https://www.elon.edu/u/imagining/time-capsule/150-years/back-1870-1940/

eMarketing. (n.d.). 16.3 Mobile Phones: More than phone calls. Retrieved June 5, 2021, from https://saylordotorg.github.io/text_emarketing-the-essential-guide-to-online-marketing/s19-03mobile-phones-more-than-phone-.html

Federal Communications Commission. (1998, December). Local Telephone Competition Report. Washington, D.C.

Federal Communications Commission. (2010, June). Local Telephone Competition Report. Washington, D.C.

Federal Communications Commission. (2017, September 8). When your Telephone Company discontinues service. Washington, D.C.

Goodwin, R. (2019, June 20). The History of Mobile Phones from 1973 to 2008: The Handsets that made it all happen. Retrieved January 6, 2021, from https://www.knowyourmobile.com/retro/thehistory-of-mobile-phones-from-1973-to-2008-the-handsets-that-made-it-all-happen-d58/

Grossman, D. (2018, April 30). On this day 25 years ago, the Web became public domain. Retrieved March 20, 2021, from https://www.popularmechanics.com/culture/web/a20104417/www-publicdomain/

Investopedia. (n.d.). What are the best metrics to evaluate a telecommunications company? Retrieved January 17, 2021, from https://www.investopedia.com/ask/answers/122414/what-are-bestmetrics-evaluate-telecommunication-company.asp

Marcus, M. (2007). 1915: The first coast-to-coast phone call in the US. Retrieved December 20, 2020, from http://4thefirsttime.blogspot.com/2007/11/1951-direct-dialing-of-long-distance.html

Melendez, S. (2019, March 20). What are the different types of cell phones? Retrieved May 24, 2021, from https:/www.techwalla.com/articles/what-are-the-different-types-of-cell-phones/

Moses, J. (2021, May). VoIP in the US Ibis World Report. Retrieved May 30, 2021, from https://www.ibisworld.com

O’Dea, S. (2021, March 19). Number of smartphone users in the United States from 2018 to 2025. Retrieved May 26, 2021, from https://www.statistica.com/statistics/201182/forecast-of smartphone-users-in-the-us/

Osbourne, M.T. (2000). The unfinished business of breaking up "Ma Bell:" Implementing local telephone competition in the twenty-first century. Journal of Law \& Technology, 7(1).

Perrin, A. (2021, January 4). The future of the telecommunication industry: Agility is key. Retrieved June 1, 2021, from https://telecoms.adaptit.tech/blog/the-future-of-the-telecommunication-industry/

Pettinger, T. (2016, November 28). Natural Monopoly. Retrieved December 19, 2020, from https://www.economicshelp.org/blog/glossary/natural-monopoly/

Rankin, B. (2021, May 10). How soon will your landline be obsolete? Retrieved May 22, 2021, from https://askbobrankin.com/how-soon-will-your-landline-be-obsolete

Roldan, P.Z. (2021). Five trends in telecom in 2021 - What to expect in the telecommunication's industry? Retrieved June 5, 2021, from https://www.atrebo.com/trends-in-telecom-for-2021

Roos, D. (n.d.). How ILECs Work. Retrieved February 26, 2021, from http://electronics.howstuffworks.com/ilec.htm

SATcase. (n.d.). Are satellite phones as popular as cell phones. Retrieved December 31, 2020, from https://www.satcase.com/satellite-phones/ 
Sims, J. (2018, October 24). AT\&T to end Analog Landline phone services? Retrieved March 20, 2021, from https://highspeedexperts.com/internet-providers/att-ending-pots/

Smith, L. (n.d.). First Commercial Telephone Exchange - Today in History: January 28. Retrieved January 5, 2021, from https://connecticuthistory.org/the-first-commercial-telephone-exchangetoday-in-history/

Snyman, J.H. (2020). The telephone: Past, present, future. Proceedings of the Western Decision Sciences Institute, April 2020.

Stone, K. (2020, August 29). The history of VoIP and Internet telephony (1928-Present). Retrieved January 11, 2021, from https://getvoip.com/blog/2014/01/27/history-of-voip-and-internettelephones/

Stone, M. (2015). The evolution of the telecommunications industry - What can we learn from it? Journal of Direct, Data and Digital Marketing Practice, 16, 157-165.

The Guardian. (2002, June 17). Bell did not invent the telephone, US Rules. Retrieved December 19, 2020, from https:/www.theguardian.com/world/2002/jun/17/humanities.internationaleducationnews

Unuth, N. (2019, November 24). An introduction to Voice over IP (VoIP). Retrieved January 11, 2021, from https://www.lifewire.com/what-is-voip-3426730

Vanderbilt, T. (2012, May 15). Hello? A visual history of the telephone. Retrieved December 19, 2020, from

https://www.slate.com/articles/life/design/2012/05/telephone_design_a_brief_history_photos.htm 1

VOIP Insights. (n.d.). VoIP history. Retrieved January 11, 2021, from https://www.voipinsights.com/voip_history.html

Wolpin, S. (2014, March 13). The first cell phone went on sale 30 years ago for \$4,000. Retrieved January 8, 2021, from https://mashable.com/2014/03/13/first-cellphone-on-sale/

Zak. (2020, March 19). The history and future of mobile phone technology. Retrieved June 17, 2021, from https://www.ecmsp.co.uk/it.blog/the-history-and-future-of-mobile-phone-technology/ 